\title{
Security Governance in East Asia and China's Response to COVID-19
}

\author{
Mely Caballero-Anthony ${ }^{1}$ [ $\cdot$ Lina Gong ${ }^{1}$ (1)
}

Received: 13 November 2020 / Accepted: 20 November 2020 / Published online: 7 February 2021

(c) Fudan University 2021

\begin{abstract}
A non-state centric approach challenged the concept of security governance in response to a changed security environment, bringing fragmentation of authority and heterarchical structures into the framework. The existing studies on this approach are largely contextualized from the European experience and developments in its security architecture. This leads to the questions as to whether and how non-state centric security governance occurs in other regions. This article contributes to the literature by studying security governance in East Asia, where the state is a dominant feature in security governance, and through the lens of non-traditional security, with China's COVID-19 response as a case study. In this particular case, we find that security governance that opens spaces for greater involvement of actors beyond the state could happen, albeit in a more circumscribed manner and subject of certain conditions. We identify three conditions that catalyze the opening of governance spaces: when the capacity of the state is stretched to the limits, when the legitimacy of the government is under pressure, and when there is trust between the government and other actors.
\end{abstract}

Keywords Security governance $\cdot$ COVID-19 response $\cdot$ Non-state actors $\cdot$ East Asia $\cdot$ China

Mely Caballero-Anthony

ismcanthony@ntu.edu.sg

1 S. Rajaratnam School of International Studies, Nanyang Technological University, Block S4B3 50 Nanyang Avenue, Singapore 639798, Singapore 


\section{Introduction}

The nature of security governance is influenced by the increasing range and complexity of security challenges and the diffusion of governance power to actors other than the state, such as international agencies, civil society, and the private sector. ${ }^{1}$ The concept and practice of security governance now increasingly involve the coordinated management and regulation of both traditional and non-traditional security issues by public and private authorities through formal and informal mechanisms (Webber et al. 2004: 4). The evolution of this approach to security governance has been well documented, with important conceptual work by scholars in Europe that analyze the practices in the European Union (EU) and the transatlantic area, where the diffusion of power among different actors is most visible (Christou et al. 2010; Ehrhart et al. 2014; Krahmann 2005; Sperling and Webber 2014).

The preoccupation with European security in the literature however overlooked the dynamics in other regions and thus limited the richness of the conceptual and theoretical debates on security governance (Ceccorulli et al. 2017: 61-65). Given the diversity and variation of security practices beyond the EU, this article contributes to the growing scholarship on security governance in other regional contexts (Breslin and Croft 2012; Sperling 2003, 2008, 2014), by focusing on East Asia (which, in this article, includes both Northeast and Southeast Asia). Specifically, given that non-traditional security (NTS) is very high on the security agenda of states in East Asia, we examine the way NTS issues are governed and address the following questions: can a more diffused pattern of security governance occur and evolve in East Asia that has a distinctly different political-security, economic and socio-cultural environment? Under what circumstances does the state allow other actors to get involved in the governance processes? What are the modes of interactions between different security providers?

In East Asia, security challenges such as great power rivalry and territorial disputes remain a real concern, given flashpoints like the South China Sea disputes and the nuclear issue in the Korean peninsula. The reality of regional security has led to a focus on traditional security and a state-centric approach in many discussions on East Asian security governance (Beeson 2014; Katsumata 2012; Uriu and Le 2014). With regard to the governance of NTS, very few examine security governance in the way it has been conceptualized in the literature. There are studies that capture certain changes happening in the region's security governance, such as the criticality of political and economic transformations in effective governance and the proliferation of security actors (Hameiri and Jones 2015; Caballero-Anthony 2018; Freedman and Murphy 2018). In this article, we develop the discussion on NTS governance in East Asia further by analyzing the extent to which the space of security governance can be opened for actors beyond the state and the circumstances that facilitate/compel the opening.

\footnotetext{
1 The literature on both governance and global governance has documented extensive discussions on diffusion of power. See, for example, Josselin and Wallace (2001), Rhodes (1996), Rosenau (1992) and Wright (1994).
} 
China's response to COVID-19 offers interesting insights on practices of security governance in East Asia. First, the immensity and gravity of the COVID-19 pandemic and the urgency of the response explain why this NTS issue belongs in the literature on security governance. Moreover, emergency measures adopted in COVID-19 responses, such as nationwide lockdown, travel bans and deployment of the military, point to the consolidation of state control over governance processes, which is opposite to the general trend of diffusion of power in security governance (Thomson and Ip 2020: 5). Second, China presents the most challenging environment for a diffused model of security governance, as the country's authoritarian system features the dominance of the Communist Party of China (CPC) in the state, particularly in the political and security spheres. Within this system, the party is able to strictly control the involvement of domestic non-state actors in the processes of security governance. Its adherence to the non-interference principle leads to a cautious approach to involving international actors. Additionally, the economic success in the past few decades has allowed the CPC to build a system with abundant resources and strong capacity to deal with NTS crises, and thus reduced its reliance on contributions from other actors.

China's highly centralized responses to fighting COVID-19 leads to the questions as to whether security governance involving both the state and other actors could happen as it dealt with an unprecedented pandemic, and under what circumstances the CPC would allow other actors to have a role in the governance processes. Our analysis finds that international agencies and non-state actors were able to find spaces to engage in China's COVID-19 response, albeit in a more circumscribed manner. There were three conditions prompting the Chinese government to allow for the engagement of actors beyond the state in this case. These were: the scale and complexity of the NTS crisis; the pressure on state legitimacy and the cost of government failure in the response, and trust engendered from the history of engagement and cooperation with the other actors.

That there were openings for non-state engagement in China's COVID-19 response supports our argument that security governance beyond the state can take place in a less conducive environment like East Asia, in a controlled and conditional way though. The findings from the case of China can be generalized to other contexts in East Asia, despite variations in factors such as the scale of NTS crises, state capacity, and state-society relations. Although the COVID-19 pandemic represents an unprecedented NTS crisis, East Asian countries have been prone to extraordinary NTS challenges that push the state to the limits of its capacity, evident in the Indian Ocean earthquake and tsunami in 2004 and the Great East Japan earthquake and tsunami and subsequent nuclear crisis in 2011. In addition, while East Asian countries vary significantly in political systems and levels of economic development, they share a general position on the centrality of the state in security governance, which will be elaborated further in the following sections. Since field research was not feasible due to travel restrictions, the research on China's COVID-19 response drew mainly from the data provided by international agencies and the Chinese government, as well as reports by international media and established Chinese media and social media platforms. Online interviews with people in China who have direct experience or close knowledge about the process were also conducted. 


\section{Evolving Security Governance in East Asia}

The nature of security governance in the EU was largely defined by a few factors, which included the emergence of the post-Westphalian state which led to the expansion of security agenda in the EU (Sperling and Webber 2014: 133), the establishment of supranational institutions in the EU that took over certain functions from national governments and became supranational security providers in their own right (Sperling 2008), and a greater role of non-state actors such as non-governmental organizations (NGOs) and the private sector in security governance (Webber et al. 2004: 5-6). The liberal political environment has been an important reason why non-state actors are able to form separate centers of authority for governance (Sperling and Webber 2014: 134). In contrast to the EU, we have seen different dynamics in East Asia, where the states' disposition to the involvement of other actors in dealing with NTS crises is generally cautious, or at best ambiguous. However, there are instances where such control is loosened, and when international agencies, foreign NGOs and domestic civil society groups get to be security providers.

\subsection{State Dominance and Broadening Security Agenda}

The role of the state in the governance processes is underpinned by its advantages over other security providers in two dimensions - material and political (Sperling and Webber 2014: 133). With its vast institutional machinery, the state has the capacity to achieve its goals given its stable access to a range of resources from fiscal, material and human resources to military force, expertise and technology. In contrast, non-state actors, such as NGOs, the private sector, and spontaneous volunteer groups that are mobilized in response to a particular NTS event, particularly the national and local ones in developing countries, often face constraints in funding, resource, experience and organization as security providers (Khieng and Dahles 2015: 1413; Parks 2008: 214). These issues can determine the way they contribute to the governance processes and lead to the ad hoc nature of their involvement in many cases. Aside from access to resources, political and normative factors are significant in shaping the state-dominated model of security governance in East Asia. In the case of disaster relief, for instance, practitioners note that nationalist sentiments affect how humanitarian operations are carried out since an appeal for international assistance risks offending national pride and thus leads to doubt in the government's capability and effectiveness in governance. ${ }^{2}$ These explain the reticence of states to open spaces for the involvement of foreign actors and domestic non-state actors in security issues, even NTS crisis.

\footnotetext{
${ }^{2}$ For instance, Said Faisal, former Executive Director of the ASEAN Coordinating Centre for Humanitarian Assistance on disaster management, discussed the impact of growing nationalism on disaster management in Southeast Asia at a webinar titled 'Humanitarian futures in the post-COVID-19 world', held on 3 June 2020. https://www.rsis.edu.sg/event/nts-centre-webinar-on-humanitarian-futures-in-the-postcovid-19-world/\#.XyKJS4gzbIU.
} 
Instead of embracing the post-Westphalian sovereignty, East Asian countries are strong proponents of Westphalian norms such as respect for sovereignty and noninterference. This normative preference heavily influences their views on the roles of regional and international institutions and non-state actors in security governance. East Asian regional frameworks such as the Association of Southeast Asian Nations (ASEAN) and the ASEAN Plus Three serve more as platforms for dialogue, cooperation and coordination. Compared with the EU which takes on the role of security provider, they are under-institutionalized, with limited capacity to act jointly to address security threats. ASEAN is an exception, as its Charter provides the legal foundation and institutional frameworks for the regional grouping to evolve into a community of ten Southeast Asian countries. Even then, the ASEAN Way that is defined by the norms of non-interference and consensus decision-making mitigates the erosion of state sovereignty and preserves the primacy of the state in security provision. While the political space for non-state actors to participate in security policy processes and practices in East Asia has expanded in recent decades, there are limits to the depth and scope of their involvement. Related regional networks and mechanisms are designed to be consultative rather than functional. The mode of participation for non-state actors is strictly regulated by governments and their ability to advance their agendas is limited (Gerard 2013).

While the political settings at national and regional levels are not conducive for a non-state-centric approach to security governance in East Asia, the region has seen the broadening of the security agenda as in the EU, due to its vulnerability to NTS threats, evident in an array of major crises in the past two decades. Some examples included the Severe Acute Respiratory Syndrome (SARS) outbreak in 2003, Cyclone Nargis in 2008, Typhoon Haiyan in 2013 and the earthquake and tsunami in Indonesia in 2018. The European practices have led to the assumption that "the changed nature of the state has conditioned and accelerated the process of securitization" (Sperling and Webber 2014: 133). In East Asia, however, the securitization of non-military problems was primarily led by national governments in the early 2000s. A good example is the invocation of NTS in the official documents in the region, such as the Joint Declaration of ASEAN and China on Cooperation in the Field of Non-traditional Security Issues in 2002 and the Memorandum of Understanding on NTS cooperation in 2004 (Arase 2010: 822). Despite the state-led nature of the securitizing move in East Asia, the broadening security agenda contributed to the opening of the security governance processes to other actors, as is demonstrated in the case study of this article that the salience of NTS crises can compel the government to allow other actors to play a greater role as security providers in certain circumstances.

\subsection{Opening Spaces for Other Actors}

In this article, we identify three factors that are likely to influence the state's attitude toward the involvement of other actors in the governance processes: the scale and complexity of the NTS problem concerned; pressures on the legitimacy of the government; and trust built from experience engaging with actors beyond the state. 


\subsubsection{Capacity Pressures}

First, the security governance space is more likely to open for the involvement of other actors when the scale and complexity of the NTS threats push governments to their limits in terms of capacity and resources. The response to typhoon Haiyan in the Philippines illustrates this. The typhoon was one of the strongest in the country's history, leaving over 6,000 people dead and millions displaced. Although the Philippine government took pre-emptive measures to mitigate its impact, it was overwhelmed by the sheer scale of the disaster (Santiago et al. 2016: 646). The UN Office for the Coordination of Humanitarian Affairs (OCHA) and other UN agencies provided critical assistance to the country's relief efforts. The Armed Forces of the Philippines received assistance from the US Pacific Command and the Japanese Self-Defence Force, which sent ships and aircraft to help in aid delivery and logistics (Salmons 2019).

Indonesia is another case in point. Due to its high vulnerability to natural hazards, the country has built strong capacity in disaster management over the years. Hence, Jakarta did not request international humanitarian aid after a 7.0 magnitude earthquake hit the island of Lombok on 5 August 2018. However, a few weeks later, when a 7.5 magnitude earthquake followed by tsunami hit the city of Palu, when the capacity and resources of Indonesia's disaster management system were still focused on the recovery efforts in Lombok, the government was compelled to appeal for international assistance (Reuters 2018).

\subsubsection{Legitimacy Pressures}

Pressures on government legitimacy are another factor that influences the government's attitude toward the participation of other actors in NTS governance. Given the salience of NTS issues in East Asia, failure to effectively manage such challenges could result in criticisms of the government's performance and political pressures from both at home and abroad. To defend and maintain its legitimacy, the government concerned is more likely to accept the participation of other actors.

During the SARS outbreak in 2003, which first started in China's Guangdong Province and spread across the globe, Beijing came under criticism by the WHO for its lack of transparency and for withholding information about the nature of the disease (Hanrieder and Kreuder-Sonnen 2014: 332). The WHO declared SARS as a threat to global public health, followed by travel advisories to affected districts and countries with major outbreaks. Under normal circumstances, such criticisms and travel advisories would have been regarded by China as interference in its domestic affairs. But the inability of the central government to rapidly contain the spread of the new virus, which was highly virulent and had no known cure, triggered public fear and anxiety. The economic fallout that followed put tremendous pressure on Beijing. In the interest of protecting its legitimacy, Beijing was pressured to cooperate with the WHO and work with its neighbors in ASEAN to contain and mitigate the transboundary impact of the disease. However, when engagement with other actors leads to doubts over the government's ability or legitimacy in governance 
like in the case of China during SARS, the space for involvement is likely to be restricted.

\subsubsection{Trust}

Third, the level of trust influences the nature and extent of involvement by other actors in the governance of NTS issues. This was seen in the aftermath of cyclone Nargis in 2008 when the Myanmar government initially refused to accept international humanitarian aid due to its distrust of Western countries and humanitarian organizations (Howe and Bang 2017: 71). It took intervention by ASEAN to persuade the government to accept foreign assistance through the Tripartite Core Group framework. The framework brought together three parties-Myanmar, the UN and ASEAN - to coordinate, facilitate and monitor the international assistance. Myanmar's trust in ASEAN underpinned the success of ASEAN's diplomacy. In China, environmental NGOs have been more visible and active in promoting environmental protection than had been expected. These NGOs gained the trust of the government by refraining from joining activities that are perceived as threatening by the government, such as public protests (Wu and Wen 2014: 112-114).

In addition, institutionalized cooperation and coordination, which cultivate a history of positive interactions among different actors, facilitate the further opening of security governance spaces. For instance, the presence of foreign military in a sovereign state is sensitive and requires a high level of mutual trust, yet military cooperation in disaster response in East Asia is not uncommon. The formal military alliance between the US and a few East Asian states has enabled the substantive involvement of the US military in disaster relief in the region, such as the response operations after the complex disaster in East Japan in 2011 and typhoon Haiyan in 2013.

\section{China's Response to COVID-19}

Many of the aforementioned nuances in security governance in East Asia and variations from the Eurocentric theories can be seen in the way China has responded to the global health crisis caused by the COVID-19 pandemic. This section shows the centrality of the state in managing an existential (security) threat, while also describing how avenues have opened for the involvement of foreign organizations and domestic non-state actors in the processes of security governance.

Drawing lessons from the SARS outbreak in 2003, China had made efforts to strengthen its public health emergency management. Since 2004, the state had introduced new legislative measures to deal with public health emergencies, a nationwide disease reporting system that covers almost the entire country, and the National Response Plan for Public Health Emergencies (Huang 2015: 92; Xue and Zeng 2019: 50). Health expenditure per capita increased from USD 133 in 2005 to USD 441 in 2017, and the percentage of health expenditure in China's gross domestic product (GDP) increased from 4.1 in 2005 to 5.2 in 2017 (WHO n.d.). With such improvements, the Chinese government could be assumed to be better prepared and equipped for another major infectious disease outbreak than in 2003. However, the 
chaos in Wuhan in the early stage of the response revealed the deficiencies in this system.

Moreover, China's political system allows for the state to have overall control in addressing an imminent security threat. The CPC which leads both the government and the military commands more resources and capacity than any other actor in the country. Nevertheless, the challenges of dealing with COVID-19 exposed major gaps in the state-dominated process in areas such as supplies, logistics and support for vulnerable groups, especially in the initial stage of the outbreak. The urgency, uncertainty and complexity of the pandemic stretched the capacity of the state to its limits. In addition, controversies over the government's handling of the early cases added to the pressures on Beijing to succeed in containing the outbreak. Against this background, we examine how diverse actors got involved in the COVID-19 response. The rest of this section examines how China responded to the COVID-19 outbreak in Wuhan, with a focus on analyzing the roles of actors other than the state.

\subsection{State-Led Emergency Response}

In December 2019, dozens of pneumonia cases of unknown cause were reported in Wuhan, the capital city of Hubei Province in central China. On 31 December, Wuhan's municipal government released an official statement about the situation in the city (Hubei Provincial Health Commission 2019). In January 2020, China began sharing information with the WHO, including an initial assessment that it was a new coronavirus and the genome sequence of COVID-19. In this period, while local authorities had put in place measures such as temperature screening, contact tracing and quarantine, life in Wuhan was largely unaffected (Zhao 2020).

The turning point came on 20 January, after a visit to Wuhan by six of the country's top medical and disease control experts dispatched by the National Health Commission (NHC). The team concluded that the new coronavirus was transmissible between humans and that frontline medical staff were already exposed (NHC 2020). Their findings prompted the CPC to securitize the new coronavirus disease. In response to the experts' findings, the State Council classified the novel coronavirus pneumonia as a Class B infectious disease on 20 January, which would allow for very strict preventive and control measures. On the same day, President Xi Jinping instructed his officials to ensure that the people's life, security and health be put first. ${ }^{3}$ At a meeting of the top CPC officials on 25 January, Xi spoke of the "battle to contain the virus". In the same meeting, the CPC established a high-level taskforce chaired by Premier Li Keqiang and a steering group to be stationed in Wuhan led by Vice Premier Sun Chunlan (Xinhua 2020a).

The securitization of the pandemic introduced extraordinary measures to contain the disease. On 22 January, Beijing ordered the lockdown of Wuhan and Hubei

\footnotetext{
3 In Xi's remarks in Chinese, the word 'anquan' was used, which means both safety and security in Chinese. But in the English version of the White Paper, it is translated as 'people's lives and health must come first'. See State Council Information Office of China. 2020. Fighting COVID-19: China in action. 7 June. http://www.xinhuanet.com/english/2020-06/07/c_139120424.htm.
} 
Province to prevent further spread of the disease. They closed the airport and railway stations, and suspended public transport, which effectively cut off Hubei, particularly Wuhan, from other parts of China. Residents were advised not to make non-essential trips out of the city from 23 January onwards (Provincial Government of Hubei 2020a, b).

As well as addressing the transmission routes of the epidemic, dealing with the cases in Wuhan was a priority. The situation had worsened rapidly, with the numbers of new cases in Wuhan surging from 4109 on 1 February to 39,462 on 15 February. ${ }^{4}$ The announcement about the outbreak on 23 January had caused public panic in the city and people rushed to hospitals for test and treatment (Kuo 2020). This resulted in severe shortages of manpower, beds and medical supplies (Fifield 2020).

The CPC started the largest mobilization of manpower and resources for a public health emergency in its history by rallying a total of over 43,000 health workers across the country to support the medical response in Wuhan and Hubei. To fill the huge gap in hospital beds in Wuhan, the municipal government transformed two scores of ordinary hospitals, built two temporary hospitals and established 16 temporary treatment centers (Xinhua 2020b). These efforts had created over 26,000 beds for COVID-19 patients with varying severity (Xinhua 2020d). The results of this unprecedented level of mobilization started to show in mid-February when the curve was flattened. The lockdown was lifted on 8 April (Xinhua 2020i). On 26 April, the last COVID-19 patient in Wuhan was discharged, marking the end of China's response in the epicenter of the outbreak.

\subsection{WHO and Other UN Agencies}

Even though the state prioritized epidemic control over other work and demonstrated strong ability to mobilize resources, China's COVID-19 response still saw the involvement of international organizations, NGOs, volunteers (self-organized and government-mobilized), private foundations, and enterprises. International organizations donated medical supplies and provided political and technical support. The WHO played the most prominent role among the international organizations operating in China, serving as a global window for updates on the situation in China and as a source of advice and guidelines for the global response. As noted earlier, the Chinese government had been sharing information with the WHO since early January. In February, a China-WHO joint expert group visited several Chinese cities to assess China's COVID-19 response, releasing a report on 25 February that described China's experience, identified lessons learned and provided recommendations for China and the world.

Various other UN agencies and intergovernmental organizations sent muchneeded supplies. The United Nations Children's Fund (UNICEF) delivered medical supplies worth of over 1 million USD to China between January and March (UNICEF 2020), while the United Nations Development Programme (UNDP)

\footnotetext{
4 Author compiled from the website of Hubei Provincial Health Commission, http://wjw.hubei.gov.cn/ bmdt/ztzl/fkxxgzbdgrfyyq/xxfb/, last accessed on 26 June 2020.
} 
donated medical supplies worth 500,000 USD in February (UNDP 2020a). The Food and Agriculture Organization of the UN (FAO) sent non-invasive ventilators, patient monitoring systems and infusion pumps in March (FAO 2020b). In the early phase of the outbreak in China, these helped alleviate the severe shortage of critical medical items. Other international agencies, such as the World Food Programme and United Nations Population Fund, also offered support (FAO 2020a).

The support of UN agencies and organizations extended beyond providing supplies. Recognizing that people living with HIV (PLHIV) in Wuhan and Hubei risked running out of anti-HIV medicines because of the containment measures (Kelland and Liu 2020), the Joint United Nations Programme on HIV/AIDS (UNAIDS) allocated a special fund to support clinics and community groups engaged in providing drug dispensing services. In addition, the agency collaborated with the Hubei government in operating a hotline to provide counselling for PLHIV and other communities. Over 4,500 people in Hubei benefited from these projects (UN 2020b).

Several information campaigns were launched, including the "Spread the Word, Not the Virus" campaign by the UNDP to promote awareness on how people could protect themselves against the virus, which reached 36 million people in China (UNDP 2020b). To increase the inclusiveness of the campaign, the organization produced videos in different Chinese dialects and solicited the participation of celebrities. On Zero Discrimination Day on 1 March 2020, the UNAIDS office in China focused on coping with discrimination against and abuse of people infected by COVID-19 (UN 2020a). As China started resuming socio-economic activities in March, the WHO and International Labour Organization (ILO) each issued guidelines on safe return to work (Xinhua 2020h; ILO 2020). These international organizations were able to leverage their authority in their respective areas of focus to complement the government's efforts to counter misinformation during the outbreak.

\subsection{NGOs and Volunteer Groups}

NGOs, private foundations, volunteer groups, and other social organizations filled gaps in medical supplies, logistics, pre-hospitalization support, counselling, community services, and protection and support for vulnerable groups. Some of the NGOs and private foundations that had previously been involved in disaster relief in China had begun monitoring the situation even before the lockdown of Wuhan and were able to move quickly. The One Foundation kicked off its response on 22 January, focusing on supply of protective equipment for frontline staff, test kits and hospital equipment, and containment efforts in communities (One Foundation 2020). Relying on its previously established network, the One Foundation had reached 996 hospitals and 521 communities in Hubei and raised over 80 million USD by the end of March. The Han Hong Love Charity Foundation called for donations on 24 January and had received about 50 million USD by 21 March. The major part of the funds, nearly 80 percent, went toward medical supplies for 271 healthcare facilities in Hubei (China Philanthropy Times 2020).

Also active in fundraising and sourcing medical supplies were alumni associations of various universities in Wuhan and Hubei. Alumni of Wuhan University in 
different cities and countries had raised over 30 million USD by mid-April (Alumni Association of Wuhan University 2020), and procured tens of thousands of masks, goggles and protective suits. Similarly, Huazhong University of Science and Technology alumni living in Germany had managed to procure 25,000 protective suits, 240,000 masks and 4000 goggles in Germany by 28 January and dispatched them to 64 hospitals across Hubei (Xiao et al. 2020).

Volunteer groups also stepped in. The Novel Coronavirus Pneumonia (NCP) Life Support, a volunteer initiative launched on the day when the lockdown was announced, mobilized 600 medical practitioners, social workers and psychological counsellors to provide pre-hospitalization medical support, which ranged from online medical consultation and counselling for patients with mild symptoms to coordination between families with critical patients and the relevant authorities (Chen 2020; Yan 2020). Between 8 and 17 February, the NCP online platform received 814 requests for help from patients and provided counselling to 412 people (Liu and Wangxu 2020). Groups of volunteer drivers were also formed to meet the surging demand for delivery and transport services during the lockdown. They provided free transport for frontline staff and patients, and delivered medical supplies to hospitals and groceries to residential communities. Initial numbers showed over 10,000 drivers joining such groups ( $\mathrm{Li}$ and $\mathrm{Xu} 2020$ ).

Aside from COVID-19 patients and their families, there were other groups that were hit hard by the outbreak, such as people with disabilities and patients with illnesses that require timely and regular treatment but could not be attended to since hospitals and government agencies in Hubei focused mostly on dealing with COVID-19 cases. Volunteer groups like the Inclusion China Network Programme of the Beijing Xiaogeng Foundation for the Disabled launched a network of emergency support on 30 January to support families with special needs (like a group of over 200 children with epilepsy who were unable to get medication) and connect them to sources of assistance (Xiao et al. 2020). A group known as "No Red Packets" helped people with serious illnesses like cancer, brain haemorrhage and chronic kidney problems in arranging for consultation and treatment (Xiao et al. 2020).

The efforts of these self-organized volunteer groups helped draw the government's attention to the needs of other vulnerable communities. In mid-February, the Wuhan municipal government designated a number of hospitals to resume certain functions for non-COVID patients with urgent needs (Xinhua 2020f). Given the help provided by these groups, the municipal government started mobilizing volunteers to assist the staff of their community management offices and government officials in managing entry points, screening high-risk populations, organizing procurement and delivery of groceries, sharing information and policies, and supporting vulnerable groups. ${ }^{5}$

\footnotetext{
${ }_{5}^{5}$ Author's interview with a volunteer in Wuhan, 15 May 2020.
} 


\subsection{Private Sector}

The pandemic also showed how business corporations contributed to emergency response. A study shows that Chinese businesses had donated over 22.4 billion RMB (4 billion USD) by 7 March (Tencent News 2020), of which 3.1 billion USD was in cash. Major donors included Tencent and Alibaba, each giving over 150 million USD. Chinese companies also contributed based on their respective strengths in areas such as logistics, communications, and production of critical items. Shunfeng Express opened additional flights between Wuhan and destinations like Beijing, Hangzhou, Shenzhen, Seoul, and Tokyo to transport critical medical supplies. Between 24 January and 6 February, the company delivered over 800 tonnes of materials to Wuhan (Shunfeng Express 2020a). Jingdong, an online shopping platform, mobilized its global supply chains, extensive network of warehouses across China, and its logistic channels to procure and deliver critical medical supplies and essentials to hospitals and residential communities in Wuhan and Hubei. In midFebruary, Jingdong Health launched an online platform to enable patients in Hubei with chronic illnesses to register for help with their medication. By matching their needs with the stocks of pharmaceutical companies and pharmacies, the platform provided critical assistance to patients running out of essential medications (Xiao et al. 2020). The important contributions of the private sector in the response were duly recognized by the appreciation letters sent by the central and local governments to the enterprises concerned, which included producers of detergents and masks as well as logistic companies (Yangtze Evening Post 2020; Tianjin Daily 2020; Shunfeng Express 2020b).

\subsection{Social Media}

Social media served as crucial platforms for communication related to the COVID19 response. UN agencies made use of their own social media accounts for the information campaigns described earlier. Many volunteer groups relied on Wechat groups to organize and share information. Weibo opened a super topic on COVID19 on 29 January, which gathered together all posts carrying the tag "COVID-19 patients seeking help" and detailed information on patients and their symptoms. In the first week, the super topic collected 500 posts and these were read 550 million times (Guancha 2020). As of 14 March 2020, the super topic had collected and verified over 10,000 related posts, with 3000 eventually reported to the relevant authorities (Manager of Super Topic 2020).

\section{Explaining the Opening of Spaces in the Governance of COVID-19}

The previous section showed how international agencies and non-state actors played a range of roles in the state-dominated response to COVID-19. In examining how governance spaces opened up for these actors, we see the same three factors we 
discussed earlier (in relation to the broadening of NTS governance in East Asia) come into focus. They are: the complexity and uncertainty of the outbreak leading to capacity gaps; the pressure on the state to succeed due to the implications for state legitimacy; and experience working with the actors concerned.

\subsection{Capacity Pressures in the COVID-19 Response}

The capacity issues in the early phase of the state-led response contributed to the opening of the space of governance to other actors. First, there was the acute shortage of medical supplies. The spokesperson for China's Foreign Ministry noted on 3 February the urgent need for medical supplies such as medical masks, protective suits, and goggles (Ministry of Foreign Affairs of China 2020). A vice mayor in Wuhan said the city was short of 41,400 protective suits, 56,800 N95 masks, and 19,200 goggles on 6 February alone (Xinhua 2020c).

The shortage was caused by several factors, including the nature and scale of the pandemic and the timing of the outbreak. The differences between COVID-19 and SARS posed challenges to China's response system, which had been largely informed by the lessons from dealing with SARS. The transmissibility of COVID19 is higher than SARS, while its clinical spectrum is different with a majority of cases showing mild or no symptoms, which increases the difficulty in conducting surveillance (Wilder-Smith et al. 2020). As a consequence, Wuhan alone saw 46,464 confirmed cases and 3869 deaths related to COVID-19 as of 30 April 2020, compared to 5327 confirmed cases and 348 deaths across China during the SARS epidemic (WHO 2003). In particular, the daily number of confirmed cases increased rapidly in between late January and early February, reaching 13,436 on 12 February. $^{6}$ The large difference in cases and deaths is indicative of the enormous pressure on the healthcare system in the city of Wuhan. Further, little was known about the virus and disease at the beginning, with the situation evolving fast; the uncertainty over the scale and duration of the outbreak increased the difficulties. ${ }^{7}$

Moreover, the outbreak unfolded just a few days before Chinese New Year, when most socio-economic activities stopped for a week-long holiday, including the production of critical medical supplies. This affected the mobilization and deployment of resources and capacity (Wang 2020). Due to the urgency in addressing the shortage, the government agreed that donations from the public and from non-state actors could be sent directly to hospitals in Wuhan, when theoretically all donations should be made to and deployed by officially designated recipients, such as the Wuhan Red Cross and the Wuhan Charity Federation in this case.

The severe lack of manpower was another major constraint facing the state-led response. While the scale of the outbreak partly explained the shortage, the features of the disease and the containment measures were also a contributing factor as the

\footnotetext{
${ }^{6}$ Author's compilation of the daily number of confirmed cases between 23 January and 23 April 2020 from the website of Hubei Provincial Health Commission, http://wjw.hubei.gov.cn/bmdt/ztzl/fkxxgzbdgr fyyq/xxfb/, last accessed on 26 June 2020.

7 Author's online interview with an expert on emergency management in China, 18 June 2020.
} 
risk of infection was a concern for many people, and volunteers outside Hubei or Wuhan were unable to enter freely. As a result, there was a severe lack of manpower in the official response. ${ }^{8}$ The involvement of other actors, particularly self-mobilized volunteer groups like NCP Life Support and Inclusion China, became necessary. Also, when Wuhan began to tighten rules for residential communities in mid-February, with residents not being allowed to step out, provision had to be made for services like procurement and delivery of groceries and essential medication. The municipal government issued a call for volunteers across the city on 23 February after the Mayor of Wuhan highlighted the importance of mobilizing local residents (Xinhua 2020e).

\subsection{Domestic and International Legitimacy at Stake}

The process and outcome of China's COVID-19 response have important implications for its domestic and international legitimacy. In the Chinese culture, disaster response has been a key mandate of the state and disasters in this context include not only natural hazards but also epidemics. Such thinking is reflected by the fact that $\mathrm{Xi}$ Jinping referred to the COVID-19 response as a major test of the CPC's governance ability (Tong 2020).

Thus, it became a concern when the Wuhan municipal government was widely criticized for its poor handling of the pandemic, particularly on the internet. Questions were raised over the mobilization and allocation of resources as media reports showed frontline medical staff being short of protective equipment particularly in the initial phase of the outbreak. Moreover, the organizations officially designated to receive public donations faced criticisms over how they managed the donations of medical supplies and cash (Guo 2020). In response, the Ministry of Civil Affairs changed the rules on the management of donations by NGOs and private foundations a few times, which gradually broadened the space for other actors to get involved in the process (Snape 2020). Public discontent heightened as several medical professionals passed away in Wuhan within a few days of each other in mid-February (Su 2020). While it is debatable whether such incidents threatened the legitimacy of the state, the CPC were under enormous pressure to successfully control the epidemic and even eliminate it in the country. This is evident from Xi's remarks in March in Wuhan that urged CPC members and officials to deliver satisfactory results in the major test (Xinhua 2020g).

The outbreak also put China's international legitimacy at stake. The Chinese government had been accused of lacking transparency in dealing with SARS. Learning from the past, China reported and shared its data on COVID-19 with the WHO early on in the outbreak. Despite the different opinions on whether such efforts were sufficient, China's cooperation with the international body rendered some legitimacy to its pandemic response. That the WHO took a careful approach in dealing with China this time, unlike during the SARS outbreak when it resorted to naming and shaming

\footnotetext{
8 Author's online interview with a volunteer in Wuhan, 15 May 2020.
} 
when Beijing was slow in responding and was deemed not transparent and cooperative, went a long way in getting China to be more willing in sharing information about the COVID-19 outbreak.

\subsection{Varying Levels of Trust}

While the important role of the WHO in China's COVID-19 response was supported by its authority as the global body for public health, trust is also an enabling factor. One indicator of a good relationship is that the WHO has been the second largest recipient of China's humanitarian funding to the UN system between 2000 and 2020, accounting for around 30 percent of such funding. ${ }^{9}$ Trust also applies to the activities of the other UN agencies during the response. In addition to the consent of the government, the agencies were supported by local partners. The social media campaigns were endorsed by Chinese goodwill ambassadors and the UNAIDS effort to support vulnerable groups was carried out by local volunteers in Wuhan.

In contrast to the established mechanisms for international agencies, coordination was a major challenge facing non-state actors (Wang 2020). Major private foundations like the One Foundation had invested in building local partnerships across China and were able to activate such networks even amid the lockdown. However, a majority of the non-state actors this time were volunteer groups that spontaneously organized during the outbreak. The contributions of these actors were constrained by a lack of access to information about the gaps in the state-led response. ${ }^{10}$ For instance, the "No Red Packets" group was only able to arrange treatment for one third of the non-COVID-19 patients who turned to them for help. The initiator of NCP Life Support attempted to seek official support for a platform providing information on the needs of hospitals in Wuhan but failed (Liu and Wangxu 2020). The inadequate engagement could be traced to health authorities and local governments in Wuhan and Hubei having limited experience in engaging with NGOs and volunteer groups (Liu and Wangxu 2020). This led to the activities of these non-state actors being largely disconnected from the official process, which undermined the effectiveness of the overall response.

\section{Conclusion}

As the security governance literature develops, it is important to include and reflect the diversity of security practices across the world to expand and enrich scholarship in this area. To advance that goal, this article examines the extent to which the Eurocentric theories of security governance are able to explain the way countries in East Asia govern NTS challenges, and how state and non-state actors negotiate the governance space in responding to NTS challenges. What we

\footnotetext{
9 The number is based on China's donations to UN agencies recorded in the Financial Tracking Service of UN OCHA, https://fts.unocha.org/data-search, accessed 20 July 2020.

10 Author's online interview with an NGO practitioner involved in the response, 12 June 2020.
} 
see is that, in East Asia, the state remains the dominant actor in the governance of NTS issues. This dominance is underpinned by the significant gap in capacity between the state and other actors, domestic institutions and regional institutions. The dominance is particularly obvious in the face of major NTS challenges like pandemic outbreaks, when the response requires a whole range of measures, from political and security to economic and diplomatic means. This state dominance challenges the assumption of European security governance theories that the changes in the post-Cold War regional and global security environment, including the rise of NTS challenges that had increased the salience and role of a multiplicity of actors, have also led to a diffusion of power among those actors. Indeed, in East Asia, the wariness of states toward certain non-state actors imposes constraints on states loosening control and allowing other actors to participate in governance processes.

At the same time, there are significant times and particular cases when diffusion of power and authority could occur, if only in a limited way. The analysis of China's response to the COVID-19 outbreak shows that in spite of the unprecedented mobilization of the state's resources to deal with the pandemic threat, many gaps existed which allowed international agencies and non-state actors to participate and contribute to containing the problem. The involvement of the WHO throughout the pandemic response lessened concerns about transparency; the donations from enterprises, alumni associations and other societal groups alleviated the shortage of medical supplies and eased the pressures on the state over resource mobilization and deployment; and the activities of volunteer groups and private foundations covered the issues left unattended by the authorities. In essence, states may loosen control over security governance under the following conditions: when the capacity of the state is stretched to the limit, when ineffective governance affects the reputation and legitimacy of the state, and when there is trust between state and non-state actors due to prior positive interactions and experience.

In conclusion, while it is important to understand the variations in security governance and to appreciate the importance of context, it does not in any way diminish the significance and contribution of the concept of security governance, particularly in highlighting the dynamic changes in the global strategic environment and how NTS issues are being governed. While the political and security milieu in East Asia matters, how security governance has evolved, the kinds of actors that have entered the security arena, and the processes that are evolving are useful markers to observe and to follow. Doing so enables us to better appreciate the possible entry points for critical interventions to be made by state and non-state actors if the aim of security is to protect and also to provide for the security needs of societies, especially vulnerable groups and communities. Security governance of NTS therefore provides another rich area for more research, not only to increase knowledge but also to inform policy in a rapidly changing security environment.

\section{Compliance with Ethical Standards}

Conflict of interest There is no conflict of interest in this paper. 


\section{References}

Alumni Association of Wuhan University. 2020. Alumni of Wuhan University making donations to support COVID-19 response. April 14. https://alumni.whu.edu.cn/info/1048/15260.htm.

Arase, David. 2010. Non-traditional security in China-ASEAN cooperation: The institutionalization of regional security cooperation and the evolution of East Asian regionalism. Asian Survey 50(4): $808-833$.

Beeson, Mark. 2014. Southeast Asia. In Handbook of governance and security, ed. James Sperling, 273288. Cheltenham: Edward Elgar Publishing.

Breslin, Shaun, and Stuart Croft, eds. 2012. Comparative regional security governance. Abingdon and New York: Routledge.

Caballero-Anthony, Mely. 2018. Negotiating governance on non-traditional security in Southeast Asia and beyond. New York: Columbia University Press.

Ceccorulli, Michela, Carlo Frappi, and Sonia Lucarelli. 2017. On regional security governance once again: How analysis of the Southern Caucasus can advance the concept. European Security 26(1): 59-78.

Chen, Huijuan. 2020. Philanthropy needs both passion and professionalism. Guangming Daily. March 7. http://epaper.gmw.cn/gmrb/html/2020-03/07/nw.D110000gmrb_20200307_1-11.htm.

China Philanthropy Times. 2020. From praise to question, Han Hong Love Charity Foundation. April 26. https://gongyi.ifeng.com/c/7vzgRnkmCGC.

Christou, George, Stuart Croft, Michela Ceccorulli, and Sonia Lucarelli. 2010. European Union security governance: Putting the 'security' back in. European Security 19(3): 341-359.

Ehrhart, Hans-Georg., Hendrik Hegemann, and Martin Kahl. 2014. Putting security governance to the test: Conceptual, empirical, and normative challenges. European Security 23(2): 119-125.

FAO. 2020a. UN food agencies offer support to China amid coronavirus outbreak. February 5. http:// www.fao.org/news/story/en/item/1259800/icode/.

FAO. 2020b. FAO donates medical supplies to China to combat COVID-19. March 14. http://www.fao. org/asiapacific/news/detail-events/en/c/1266190/.

Fifield, Anna. 2020. In Wuhan's virus wards, plenty of stress but shortages of everything else. Washington Post. January 25. https://www.washingtonpost.com/world/asia_pacific/in-wuhans-virus-wards -plenty-of-stress-but-shortages-of-everything-else/2020/01/24/ba1c70f0-3ebb-11ea-afe2-090eb 37b60b1_story.html.

Freedman, Amy L., and Ann Marie Murphy. 2018. Nontraditional security challenges in Southeast Asia: The transnational dimension. Boulder: Lynne Rienner Publishers.

Gerard, Kelly. 2013. From the ASEAN People's Assembly to the ASEAN Civil Society Conference: The boundaries of civil society advocacy. Contemporary Politics 19(4): 411-426.

Guancha. 2020. COVID-19 patients can seek help through Weibo's super topic. February 5. https://www. guancha.cn/ChanJing/2020_02_05_534647.shtml.

Guo, Rui. 2020. State-backed charity in Wuhan under fire over coronavirus donations. South China Morning Post. February 14. https://www.scmp.com/news/china/society/article/3050545/state-backe d-charity-wuhan-under-fire-over-coronavirus-donations.

Hameiri, Shahar, and Lee Jones. 2015. Probing the links between political economy and non-traditional security. International Politics 52(4): 371-388.

Hanrieder, Tine, and Christian Kreuder-Sonnen. 2014. WHO decides on the exception? Securitization and emergency governance in global health. Security Dialogue 45(4): 331-348.

Howe, Brandon, and Bang Geehyung. 2017. Nargis and Haiyan: The politics of natural disaster management in Myanmar and the Philippines. Asian Studies Review 41(1): 58-78.

Huang, Yanzhong. 2015. Governing health in contemporary China, 1st ed. Abingdon and New York: Routledge.

Hubei Provincial Health Commission. 2019. Bulletin of Wuhan Municipal Health Commission on the pneumonia cases in the city. December 31. http://wjw.hubei.gov.cn/fbjd/dtyw/201912/t2019 1231_1822343.shtml.

ILO. 2020. Safe return to work: Guide for employers on COVID-19 prevention. https://www.ilo.org/ wcmsp5/groups/public/---ed_dialogue/---act_emp/documents/publication/wcms_744033.pdf.

Josselin, Daphné, and William Wallace. 2001. Non-state actors in world politics: A framework. In Nonstate actors in world politics, ed. Daphné Josselin and William Wallace, 1-20. Hampshire and New York: Palgrave. 
Katsumata, Hiro. 2012. East Asian regional security governance: Bilateral hard balancing and ASEAN's informal cooperative security. In Comparative regional security governance, ed. Shaun Breslin and Stuart Croft, 72-93. Abingdon and New York: Routledge.

Kelland, Kate, and Roxanne Liu. 2020. China HIV patients risk running out of AIDS drugs in days: UNAIDS. Reuters. February 19. https://www.reuters.com/article/us-china-health-aids-idUSK BN20D1RE.

Khieng, Sothy, and Heidi Dahles. 2015. Resource dependence and effects of funding diversification strategies among NGOs in Cambodia. VOLUNTAS: International Journal of Voluntary and Nonprofit Organizations 26(4): 1412-1437.

Krahmann, Elke. 2005. Security governance and networks: New theoretical perspectives in transatlantic security. Cambridge Review of International Affairs 18(1): 15-30.

Kuo, Lily. 2020. Birth of a pandemic: Inside the first weeks of the coronavirus outbreak in Wuhan. Guardian. April 10. https:/www.theguardian.com/world/2020/apr/10/birth-of-a-pandemic-insid e-the-first-weeks-of-the-coronavirus-outbreak-in-wuhan.

Li, Ting, and Xu Kuang. 2020. Wuhan: Over 10,000 drivers volunteered. Hubei Daily. February 2. http:// www.wenming.cn/zyfw/rd/202002/t20200202_5403434.shtml.

Liu, Yixian, and Wangxu Qiulin. 2020. Issues in civil society's response to the COVID-19 outbreak in Hubei. Special Issue on COVID-19 Response. Southern Weekly. February 29. https://new.qq.com/ omn/20200229/20200229A0FECP00.html.

Manager of Super Topic. 2020. Weibo super topic collected over 10,000 help-seeking posts. March 14. https://weibo.com/5936018176/IyzZ5pe6y?type=comment.

Ministry of Foreign Affairs of China. 2020. Foreign Ministry spokesperson Hua Chunying's daily briefing online on February 3, 2020. https://www.fmprc.gov.cn/mfa_eng/xwfw_665399/s2510_66540 1/2511_665403/t1739548.shtml.

NHC. 2020. NHC high-level expert group answer questions on the coronavirus pneumonia outbreak from the media. January 21. http://www.nhc.gov.cn/xcs/s7847/202001/8d735f0bb50b45af928d9944d $16950 \mathrm{c} 8$. shtml.

One Foundation. 2020. Summary of One Foundation's work during the COVID-19 outbreak. April 17. http://www.onefoundation.cn/index.php/index.php?m=article\&a=show\&id=1254.

Parks, Thomas. 2008. The rise and fall of donor funding for advocacy NGOs: Understanding the impact. Development in Practice 18(2): 213-222.

Provincial Government of Hubei. 2020a. Bulletin of Wuhan Municipal Government on emergency transport measures after the shutdown of the city. January 23. https://www.hubei.gov.cn/zhuanti/2020/ gzxxgzbd/zxtb/202001/t20200123_2014524.shtml.

Provincial Government of Hubei. 2020b. Governor of Hubei on the closure of paths leaving Wuhan. January 23. https://www.hubei.gov.cn/zwgk/hbyw/hbywqb/202001/t20200123_2014604.shtml.

Reuters. 2018. Indonesia tells independent foreign aid workers to leave earthquake zone. October 9. https ://www.straitstimes.com/asia/se-asia/indonesia-tells-independent-foreign-aid-workers-to-leave-earth quake-zone.

Rhodes, R.A.W. 1996. The new governance: Governing without government. Political Studies 44: 652-667.

Rosenau, James N. 1992. Governance, order, and change in world politics. In Governance without government: Order and change in world politics, ed. James N. Rosenau and Earnest-Otto Czempiel, 1-29. Cambridge: Cambridge University Press.

Salmons, Richard. 2019. Disaster relief, international status and regional order: A case study of Typhoon Haiyan. Global Change, Peace \& Security 31(3): 283-301.

Santiago, J Sedfrey S, Wilfred S Manuela Jr, Marion Lara L Tan, Siegfried Kiel Sañez, and Aldo Zelig U Tong. 2016. Of timelines and timeliness: Lessons from Typhoon Haiyan in early disaster response. Disasters 40(4): 644-667.

Shunfeng Express. 2020a. Shunfeng cargos transported over 800 tonnes of critical medical supplies. February 6. https://www.sf-express.com/cn/sc/news/detail/800/

Shunfeng Express. 2020b. Shunfeng Express received letter of appreciation from Wuhan Municipal Government. April 22. https://www.sf-express.com/cn/sc/news/detail/-01371/.

Snape, Holly. 2020. China alters civil society rules, allowing more groups to respond to Coronavirus. ChinaFile. March 5. https://www.chinafile.com/ngo/analysis/china-alters-civil-society-rules-allow ing-more-groups-respond-coronavirus.

Sperling, James. 2008. State attributes and system properties: Security multilateralism in central Asia, Southeast Asia, the Atlantic and Europe. In Multilateralism and security institutions in an era of 
globalization, ed. Dimitris Bourantonis, Kostas Ifantis, and Panayotis Tsakonas, 101-135. Abingdon and New York: Routledge.

Sperling, James. 2014. Regional security governance. In Handbook of governance and security, ed. James Sperling, 98-119. Cheltenham: Edward Elgar Publishing Limited.

Sperling, James. 2003. Eurasian security governance: New threats, institutional adaptations. In Limiting institutions? The challenge of Eurasian security governance, ed. James Sperling, Sean Kay, and S. Victor Papacosma, 3-23. Manchester: Manchester University Press.

Sperling, James, and Mark Webber. 2014. Security governance in Europe: A return to system. European Security 23(2): 126-144.

Su, Alice. 2020. California coronavirus cases: Tracking the outbreak. Los Angeles Times. https://www. latimes.com/projects/california-coronavirus-cases-tracking-outbreak/embed/.

Tencent News. 2020. Release of first report on enterprises fulfilling social responsibility in response to COVID-19. May 16. https://finance.qq.com/a/20200516/006730.htm.

Thomson, Stephen, and Eric C. Ip. 2020. COVID-19 emergency measures and the impending authoritarian pandemic. Journal of Law and the Biosciences. https://doi.org/10.1093/jlb/lsaa064.

Tianjin Daily. 2020. Teda Filters received letter of appreciation from the State Council. March 22. http:// www.tj.xinhuanet.com/news/2020-03/22/c_1125750014.htm.

Tong, Xin. 2020. COVID-19 response: A major test for our governance system. Qiushi. March 1. http:// www.qstheory.cn/dukan/qs/2020-03/01/c_1125641760.htm.

UN. 2020a. Zero Discrimination Day: More tolerance and love amid pandemic. March 1. https://news. un.org/zh/story/2020/03/1051781.

UN. 2020b. UNAIDS donate N95 masks to Hubei Provincial CDC. March 16. https://news.un.org/zh/ story/2020/03/1052822.

UNDP. 2020a. Second shipment of UNDP donated emergency medical supplies arrives in Beijing. February 27. https://www.cn.undp.org/content/china/en/home/presscenter/articles/2020/second-shipmentof-undp-donated-emergency-medical-supplies-arriv.html.

UNDP. 2020b. Spread the word, not the virus: Engaging 36 million people in the fight against COVID19. March 20. https://www.cn.undp.org/content/china/en/home/ourperspective/ourperspectivearticl es/2020/spread-the-word--not-the-virus--engaging-36-million-people-in-th.html.

UNICEF. 2020. UNICEF flies in additional 12 tons of supplies to support China's response to COVID19. March 1. https://www.unicef.cn/en/press-releases/unicef-flies-additional-12-tons-supplies-suppo rt-chinas-response-covid-19.

Uriu, Rorbert M., and Tome Le. 2014. Northeast Asia. In Handbook of governance and security, ed. James Sperling, 188-215. Cheltenham: Edward Elgar Publishing Limited.

WHO. 2003. Cumulative number of reported probable cases of SARS. https://www.who.int/csr/sars/ country/2003_07_11/en/.

WHO. n.d. Health expenditure profile: China. WHO global health expenditure database. https:// public.tableau.com/shared/J92W85QMQ?:embed=y\&:showVizHome=no\&:host_url=https $\% 3 \mathrm{~A} \% 2 \mathrm{~F} \% 2 \mathrm{Fpublic} . t a b l e a u . c o m \% 2 \mathrm{~F} \&:$ embed_code_version=3\&:toolbar=yes\&:animate_trans ition=yes\&:display_static_image $=$ no\&:display_spinner $=$ no\&:display_overlay=yes\&:display_count $=$ yes\&publish=yes $\&:$ loadOrderID $=0$. Accessed 20 July 2020.

Wang, Zhenyao. 2020. COVID-19 outbreak is unprecedented. Caijing Magazine. February 22. https:// news.caijingmobile.com/article/detail/412695? source_id $=40$.

Webber, Mark, Stuart Croft, Jolyon Howorth, Terry Terriff, and Elke Krahmann. 2004. The governance of European security. Review of International Studies 30(1): 3-26.

Wilder-Smith, Annelies, Calvin J. Chiew, and Vernon J. Lee. 2020. Can we contain the COVID-19 outbreak with the same measures as for SARS? The Lancet Infectious Diseases 20(5): e102-e107. https ://doi.org/10.1016/S1473-3099(20)30129-8.

Wright, Vincent. 1994. Reshaping the state: The implications for public administration. Western European Politics 17 (3): 102-137.

Wu, Fengshi, and Bo Wen. 2014. Nongovernmental organizations and environmental protests. In Routledge handbook of environment and society in Asia, 1st ed., ed. Paul Harris and Graeme Lang, 105119. Abingdon: Routledge.

Xiao, Hui, Zhao Ning, and Ding Jie. 2020. Help Wuhan, social self-help network in making. Caixin Weekly. February 24. http://weekly.caixin.com/2020-02-22/101518909.html.

Xinhua. 2020a. Xi Focus: CPC leadership meets to discuss novel coronavirus prevention, control. January 25. http://www.xinhuanet.com/english/2020-01/25/c_138733715.htm. 
Xinhua. 2020b. Two temporary hospitals under construction. February 2. http://www.xinhuanet.com// $\mathrm{mrdx} / 2020-02 / 02 / \mathrm{c} \_138749165 . h t m$.

Xinhua. 2020c. Severe shortage in medical supplies in Wuhan. February 8. http://www.xinhuanet.com/ local/2020-02/08/c_1125544896.htm.

Xinhua. 2020d. Wuhan increases designated hospitals for COVID-19 patients. February 12. http://www. xinhuanet.com/english/2020-02/12/c_138778248.htm.

Xinhua. 2020e. To complete city-wide screening by 19th February. February 19. http://www.xinhuanet. com/2020-02/19/c_1125593622.htm

Xinhua. 2020f. Treatment for non-COVID patients not to be halted. February 24. http://www.xinhuanet. com/politics/2020-02/24/c_1125620343.htm.

Xinhua. 2020g. Xi Jinping visiting Hubei to review COVID-19 response. March 10. http://www.xinhu anet.com/politics/leaders/2020-03/10/c_1125692140.htm.

Xinhua. 2020h. Hygiene measures after resuming economic activities. March 22. http://www.xinhuanet. com/politics/2020-03/22/c_1125751008.htm.

Xinhua. 2020i. Wuhan coming out of lockdown. April 8. http://www.xinhuanet.com/2020-04/08/c_11258 30000.htm.

Xue, Lan, and Zeng Guang. 2019. A Comprehensive evaluation on emergency response in China: The case of pandemic influenza (H1N1) 2009. Singapore: Springer.

Yan, Xingyue. 2020. NCP Life Support: Trying to save more. Beijing Headlines. February 13. https:// app.bjtitle.com/new/newshow.php?newsid=5545225\&src=stream\&typeid=93.

Yangtze Evening Post. 2020. State Council sent letter of appreciation to enterprise in Jiangsu. March 29. http://news.sina.com.cn/o/2020-03-29/doc-iimxyqwa3927496.shtml.

Zhao, Yusha. 2020. Controversial Baibuting speaks up on banquet. Global Times. April 25. https://www. globaltimes.cn/content/1186702.shtml.

Mely Caballero-Anthony is Professor and Head of the Centre for Non-Traditional Security (NTS) Studies at the S. Rajaratnam School of International Studies (RSIS), Nanyang Technological University, Singapore. Her research interests include global governance and multilateral security cooperation, nontraditional security and human security, and regionalism and regional security in the Asia-Pacific. She has published extensively in peer-reviewed journals and international presses. Her latest books include: Negotiating Governance on Non-Traditional Security in Southeast Asia and Beyond (New York: Columbia University Press, 2018)

Lina Gong is Research Fellow at the Centre for Non-Traditional Security (NTS) Studies, S. Rajaratnam School of International Studies (RSIS), Nanyang Technological University (NTU). Her research interests include non-traditional security studies in East Asia, humanitarian affairs, China's foreign policy and China-Southeast Asia relations. 